\title{
A PURPLE NON-SULFUR BACTERIUM PRODUCING POLYHYDROXYBUTYRATE AND THE CONSERVED REGION OF PHA SYNTHASE GENE
}

\author{
BACTÉRIA PÚRPURA NÃO SULFUROSA PRODUTORA DE \\ POLIHIDROXIBUTIRATO E A REGIÃO CONSERVADA DO GENE PHA SINTASE
}

\author{
Somporn TANSKUL; Supaporn SRISAI; Aekkaraj NUALLA-ONG \\ Department of Molecular Biotechnology and Bioinformatics, Faculty of Science, Prince of Songkla University, \\ Hat Yai 90112, Thailand. somporn.t@psu.ac.th
}

\begin{abstract}
This study aimed to screen purple non-sulfur bacteria capable of accumulating granules or polyhydroxybutyrate (PHB) inside the cells, identify the potent strain, assay the enzyme or PHA synthase, and compare the PHB synthase gene with that of related strains. A total of 58 strains of purple non-sulfur bacteria were isolated from 108 samples of chicken feces in the chicken-egg farm of the Department of Animal Science, Faculty of Natural Resources at Prince of Songkla University, Hat Yai, Thailand. After cultivating the bacteria in glutamate malate (GM) medium without added glutamic acid under light $(3,000 \mathrm{Lux})$ at $35^{\circ} \mathrm{C}$ for 5 days, the intracellular biopolymer granules of the bacteria were observed by using a Confocal Laser Scanning Microscope (CLSM) with excitation and emission wavelength of 530 and $605 \mathrm{~nm}$, respectively. Gas chromatography (GC) was carried out for quantitative analysis of PHB. There were five strains, $\mathrm{CH} 12, \mathrm{CH} 52, \mathrm{CH} 72, \mathrm{CH} 90$ and $\mathrm{CH} 92$, showed biopolymer granules under CLSM, and accumulated PHB 5, $1.7,1.5,1.4$ and $1.8 \%\left(\mathrm{w} \mathrm{w}^{-1}\right)$ of the cell dry weight $(\mathrm{CDW})$, respectively. The $16 \mathrm{~S}$ rDNA sequence analysis of CH12 strain showed a high homology of $100 \%$ correlation to that of Rhodopseudomonas palustris strain NCIB8288. Regarding the taxonomic characteristics and 16S rDNA sequence analysis, CH12 strain was identified as Rps. palustris NCIB8288. The PHA synthase activity of the crude extract from $\mathrm{CH} 12$ strain was 25 units $/ \mathrm{mL}$. The conserved regions could be aligned and selected among 5 strains of Rhodopseudomonas palustris (strains BisA53, TIE-1, CGA009, HaA2 and BisB18). The purified PCR product was obtained for further studies.
\end{abstract}

KEYWORDS: Chicken feces. Rhodopseudomonas palustris. Bioplastic. Polyhydroxybutyrate. phaC gene. Conserved region.

\section{INTRODUCTION}

Plastics are not environmentally friendly materials to the circumstances due to the long-term degradation. Although polyhydroxyalkanoate (PHA) is one of candidates for biodegradable plastics such as polylactides, aliphatic polyesters, polysaccharides, and the copolymers and/ or blends of these, it has attracted much interest because of its biodegradability and similar properties to conventional plastics (BYROM, 1994). There are about 150 kinds of hydroxyalkanoic acids as monomers of PHAs (STEINBüCHEL; VALENTIN, 1995) like inclusions or granules in the cell (DUNLOP; ROBARDS, 1973). The first PHA is the homopolymer poly(3-hydroxybutyrate) (PHB) found in 1925 by Maurice Lemoigne (JACKSON; SRIENC, 1994). PHAs are found in various kinds of microorganisms as energy and carbon reserve (SALEHIZADEH; LOOSDRECHT, 2004) under aerobic condition (GOBI; VADIVELU, 2014). They can be found in natural environments, for example, lake (ESTEVE et al., 1996), river (LOPEZ et al., 1995), knots of plant rhizoids (NDOYE et al.,
1994), deep sea under high temperature (GUEZENNEC et al., 1998), and activated sludge (MINO et al., 1998). They can be observed in bacteria under unusual growth conditions or depletion of an essential nutrient other than the carbon source (ALDERETE et al., 1993).

Purple non-sulfur bacteria is a group of purple bacteria. They are heterotrophs using organic substrates, e.g. acetate, pyruvate and dicarboxylic acids. They are able to grow under aerobic, anaerobic and microaerobic conditions with light or without light. Nevertheless, they grow well under anaerobic to microaerobic condition with light. They also grow well in polluted environments (KOBAYASHI et al., 1978) which is well known for using them in wastewater treatments (KOBAYASHI; KOBAYASHI, 1995). The purple non-sulfur bacteria, for instance, Rhodobacter sphaeroides (KHATIPOV et al., 1998; BRANDL et al., 1991) and Rhodospirillum rubrum (BRANDL et al. 1991) are capable of producing PHBs. Thus, it is an expedient to get PHBs in purple non-sulfur bacteria using low-cost medium with environmental advantages. The aim of this study was to screen the 
A purple non-sulfur bacterium...

potent strain which could produce PHBs from chicken feces, the PHA synthase assay and information of the conserved region of PHA synthase gene and primer design for the gene amplification. Further study on genetic manipulation to increase the PHB yield will have been carried out.

\section{MATERIAL AND METHODS}

A total of 108 samples of chicken feces in the chicken-egg farm of the Department of Animal Science, Faculty of Natural Resources at Prince of Songkla University, Hat Yai were used for isolation of purple non-sulfur bacteria. Glutamate-malate (GM) medium was prepared for growing the purple non-sulfur bacteria. $12.5 \mathrm{~mL}$ of $\mathrm{GM}$ medium without added glutamic acid in a $15-\mathrm{mL}$ screw-cap tube used for cultivation of the bacteria. The starter used was 5\% ( $\left.\mathrm{v} \mathrm{v}^{-1}\right)$ and incubated under microaerobic condition with tungsten light intensity of $3,000 \mathrm{Lux}$ at $35^{\circ} \mathrm{C}$ for $48 \mathrm{~h}$. It was then centrifuged at $12,000 \mathrm{rpm}$ for $5 \mathrm{~min}$. The cell pellet was washed with $0.85 \%$ saline solution and freeze-dried for further study.

The 5-day incubation time of the strain was smeared and heat fixed on a glass slide. $1 \%$ aqueous solution of Nile blue A was used as a staining of PHB granules at $55^{\circ} \mathrm{C}$ for $10 \mathrm{~min}$. It was then washed with tap water and $8 \%$ acetic acid solution for $1 \mathrm{~min}$, respectively. It was washed with distilled water and blotted dry. The slide was remoistened with distilled water and covered with glass cover slip before observing by Confocal Laser Scanning Microscope (CLSM) with excitation and emission wavelength of 530 and $605 \mathrm{~nm}$, respectively. The procedure was followed using the Holt and Ostle method (HOLT; OSTLE, 1982). Azotobacter sp. TISTR 1094 was used as a reference strain.

The method of esterification of PHB for GC analysis was followed according to the protocol described by Riis and Mai (RIIS; MAI, 1988). 20-40 $\mathrm{mg}$ of freeze dried bacterial cells was weighed and put into a $10 \mathrm{~mL}$ tightly sealable vial. It was added with $2 \mathrm{~mL} 1,2$-dichloroethane (DCE), $2 \mathrm{~mL} \mathrm{n}$ propanol containing hydrochloric acid $(\mathrm{HCl})(1$ volume of concentrated $\mathrm{HCl}$ mixed with 4 volumes of n-propanol) and $200 \mu \mathrm{L}$ internal standard (two gram of benzoic acid in $50 \mathrm{~mL}$ n-propanol). The mixture was shaken intermittently in water bath at $85^{\circ} \mathrm{C}$ for $4 \mathrm{~h}$. It was then cooled to room temperature, added with $4 \mathrm{~mL}$ distilled water, and shaken for 20-30 sec, respectively. To determine the PHB content of the cells, the heavier phase or the DCE-propanol was collected and injected into the
TANSKUL, S; SRISAI, S.; NUALLA-ONG, A.

GC. The ratio of PHB to cell dry weight was defined as the PHB content.

The column used for determination of PHB by GC was HP-1 (HP 19091Z-413E, Crosslinked Methyl Siloxane, Hewlett Packard, USA) capillary column, $30 \mathrm{~m}$ in length with $0.32 \mathrm{~mm}$ inner diameter. The injection port and the flame ionization detector (FID) port was operated at $250^{\circ} \mathrm{C}$. The following temperature profile used was $5 \mathrm{~min}$ at $80^{\circ} \mathrm{C}$, followed by $7^{\circ} \mathrm{C} / \mathrm{min}$ rise to reach the final temperature of $200^{\circ} \mathrm{C}$. Nitrogen with the flow rate of $5 \mathrm{~mL} / \mathrm{min}$ was used as the carrier gas. Injection volume was $1.0 \mu \mathrm{L}$ and injection mode was splitless. A double flame ionization detector (FID) combined with a computer controlling gas chromatography (HP 6850) was used for analysis. To calibrate the GC, $200 \mathrm{mg}$ of PHB was dissolved with a small volume of DCE by heating in a calibrated $10-\mathrm{mL}$ flask. It was then cooled to room temperature and made up to $10 \mathrm{~mL}$ by distilled water. The solution was esterified as mentioned above, and injected to GC with the volume of 200; 400; 600; 800 and $1000 \mu \mathrm{L}$.

CH12 strain was identified based on the taxonomic characteristics according to the Bergey's Manual of Systematic Bacteriology (PFENNIG; TRUPER, 1989), and 16S rDNA sequence analysis. According to the standard method (SAMBROOK et al., 1989), the genomic DNA was extracted after cultivating the strain in GM medium under microaerobic condition with light $(2,500 \mathrm{Lux})$ at $35^{\circ} \mathrm{C}$ for $12 \mathrm{hr}$. Universal primers, position 170 for forward and 705 for reverse, were used to amplify the gene using GeneAmp PCR System 9600. The length of PCR product was $537 \mathrm{bp}$. It was sequenced using API 377 DNA sequencer.

After cultivating Rps. palustris $\mathrm{CH} 12$ for 3 days, the grown cells were harvested $(0.62 \mathrm{~g}$ of wet cells from $100-\mathrm{mL}$ culture). It was then suspended in $5.0 \mathrm{~mL}$ of $10 \mathrm{mM}$ Tris- $\mathrm{HCl}$ buffer $\mathrm{pH} 7.5$, and centrifuged at $10,000 \mathrm{rpm}, 4^{\circ} \mathrm{C}$ for $5 \mathrm{~min}$. The pellet of cells was put on ice and added $1.5 \mathrm{~mL}$ of extraction buffer (10 mM Tris- $\mathrm{HCl}$ buffer $\mathrm{pH} 7.5$ containing $10 \mathrm{mM}$ EDTA, and $1 \mathrm{mM}$ DTT). It was mixed well by vortex mixer, and then sonicated for $5 \mathrm{~min}$, and paused every $15 \mathrm{sec}$ for $5 \mathrm{sec}$. The sonicated mixture was centrifuged at $10,000 \mathrm{rpm}, 4^{\circ}$ $\mathrm{C}$ for $5 \mathrm{~min}$. The supernatant was kept at $4^{\circ} \mathrm{C}$ for PHA synthase assay.

PHA synthase was assayed by a modified method of Dai and Reusch (DAI; REUSCH, 2008). The substrate, $0.88 \mathrm{mM}$ DL- $\beta$-hydroxybutyryl coenzyme A was dissolved in $10 \mathrm{mM}$ Tris- $\mathrm{HCl}, \mathrm{pH}$ 7.5. The reaction mixture contained $0.088 \mathrm{mM}$ DL$\beta$-hydroxybutyryl coenzyme A, $100 \mathrm{mM} \mathrm{KCl}$, and 
$100 \mu \mathrm{L}$ supernatant of sonicated cells. It was incubated at $37^{\circ} \mathrm{C}$ for $30 \mathrm{sec}$. The reaction mixture was stopped by adding $20 \mu \mathrm{L}$ of $0.44 \mathrm{M}$ TCA. It was then centrifuged at 12,000 rpm for $5 \mathrm{~min}$. A 102 $\mu \mathrm{L}$-supernatant was pipetted into an eppendorf tube, and added with $573 \mu \mathrm{l}$ of $1 \mathrm{mM} 5,5$ '-dithiobis-(2nitrobenzoic acid). The coenzyme A concentration was measured spectrophotometrically at $412 \mathrm{~nm}$. Duplicate assays and a blank reaction were carried out. For determination of enzymatic activity, standard curve was performed at the same conditions. One unit of enzyme is defined as an amount of enzyme which catalyze $1 \mu \mathrm{mol}$ DL- $\beta$ hydroxybutyryl coenzyme A into coenzyme A per min under the assay conditions.

In order to get multiple sequence alignment, the Clustal X program was used.

A highly conserved region was selected and used for primer design. The forward and reverse primers were approved by Vector NTI program. The PHA synthase gene was amplified 35 cycles with a $2-\mathrm{sec}$, $55^{\circ} \mathrm{C}$ denaturation step, a $30-\mathrm{sec}, 52.5^{\circ} \mathrm{C}$ annealing step, a 2-sec, and $72^{\circ} \mathrm{C}$ extension step. The PCR product was purified by PureLinkTM Quick Gel Extraction Kit (Invitrogen) and analyzed on $1 \%$ agarose gel electrophoresis.

\section{RESULTS AND DISCUSSION}

TANSKUL, S; SRISAI, S.; NUALLA-ONG, A.

A total of 58 strains of purple non-sulfur bacteria could be isolated from 108 samples of chicken feces under micro-aerobic conditions with light. After cultivating 58 strains of purple nonsulfur bacteria in GM medium without added glutamic acid under micro-aerobic conditions under light $(3,000 \mathrm{Lux})$ at $35^{\circ} \mathrm{C}$ for 5 days, only five strains: $\mathrm{CH} 12, \mathrm{CH} 52, \mathrm{CH} 72, \mathrm{CH} 90$ and $\mathrm{CH} 92$, showed biopolymer granules under fluorescence microscopy and accumulated PHB 5; 1.7; $1.5 ; 1.4$ and $1.8 \%\left(\mathrm{w} \mathrm{w}^{-1}\right)$ of the CDW, respectively, analysed by using GC. The results do not correlate to those of other purple non-sulfur bacteria, for example, Rhodospirillum rubrum and Rhodobacter sphaeroides (Rba. sphaeroides) are able to accumulate PHA under nitrogen-limited source conditions $45 \%$ and $60-70 \%$, respectively (BRANDL et al. 1989; BRANDL et al. 1991), and Rba. sphaeroides accumulate PHB higher in lactateglutamate than in lactate-ammonium medium (KHATIPOV et al. 1998). However, PHB accumulation of the five strains was higher than that of the type strain, Azotobacter sp. TISTR 1094, $1.1 \%\left(\mathrm{w} \mathrm{w}^{-1}\right)$ of the CDW. The CH12 strain was selected as the most potent strain for further study.

The CH12 strain was identified as Rhodopseudomonas palustris (Rps. palustris) strain NCIB8288 based on the taxonomic characteristics (Table 1) and 16S rDNA sequence analysis (Figure 1).

Table 1. Comparison of the characteristics of Rhodopseudomonas palustris and CH12 strain

Characteristics Rhodopseudomonas palustris* CH12 strain

$\begin{array}{ccc}\text { Gram staining } & \text { negative } & \text { negative } \\ \text { Cell shape } & \text { rod } & \text { rod } \\ \text { Flagellation } & 1, \text { polar } & \text { 1, polar } \\ \text { Photoautotrophic growth } & + & + \\ \text { Carbon sources and photosynthetic electron donors } & \\ \text { Acetate } & + & + \\ \text { Butyrate } & + & + \\ \text { Citrate } & + & + \\ \text { Gluconate } & \text { ND } & + \\ \text { Glucose } & \pm & - \\ \text { Fructose } & \pm & + \\ \text { Sorbitol } & + & + \\ \text { Glycerol } & + & + \\ \text { Ethanol } & + & + \\ \text { Thiosulfate } & + & -\end{array}$

Symbols: *, Imhoff; Truper, 1989

+ , positive; -, negative; \pm , positive in some strains but negative in other

strains; ND, not determined. 


\begin{tabular}{|lllll|}
\hline aagtcagagg & tgaaagcctg & gagctcaact & ccagaactgc & cttgatact \\
ggaagtcttg & agtatggcag & aggtgagtgg & aactgcgagt & gtagaggtga \\
aattcgtaga & tattcgcaag & aacaccagtg & gcgaaggcgg & ctcactgggc \\
cattactgac & gctgaggcac & gaaagcgtgg & ggagcaaaca & ggattagata \\
ccctggtagt & ccacgccgta & aacgatgaat & gccagccgtt & agtgggtta \\
ctcactagtg & gcgcagctaa & cgcttaagc & attccgcctg & gggagtacgg \\
tcgcaagatt & aaaactcaaa & ggaattgacg & ggggcccgca & caagcggtgg \\
agcatgtggt & ttaattcgac & gcaacgcgca & gaaccttacc & agccettgac \\
atgtccagga & ccggtcgcag & agacgcgacc & ttctcttcgg & agcctggagc \\
acaggtgctg & catggctgtc & gtcagctcgt & gtcgtgagat & gttgggttaa \\
gtcccgcaac & gagcgcaacc & cccgtcctta & gttgcta & \\
& & & & \\
\hline
\end{tabular}

Figure 1. 16S rDNA sequence of CH12 strain.

The evolutionary tree between Rps. palustris strain NCIB8288 and other bacteria showed that Rps. palustris strain NCIB8288 has close evolution to Rps. palustris strain KD1 (92.9\%), Rps. palustris strain BIS3 (90.3\%), Rps. palustris strain $\mathrm{N} 1$ (82.8\%) and Rps. palustris strain TIE-1 (20.9\%) (Fig. 2). Earlier reports on Rps. palustris producing PHB (de PHILLIPPIS et al. 1992; SAWAYAMA et al. 2000; SAWAYAMA et al. 2001; CARLOZZI; SACCHI, 2001; MUKHOPADHYAY et al., 2005) also point at the same results. The PHB accumulation of CH12 strain was low, $21 \%\left(\mathrm{w} \mathrm{w} \mathrm{w}^{-1}\right)$ of the CDW, compared to those of other bacteria such as Methylobacterium extorquens (46\% $\left(\mathrm{w} \mathrm{w}^{-1}\right)$ of the CDW) (BOURQUE et al., 1995), Pseudomonas sp. K $\left(66 \%\left(\mathrm{w} \mathrm{w}^{-1}\right)\right.$ of the CDW) (SUZUKI et al., 1986),
Alcaligenes eutrophus $\left(76 \%\left(\mathrm{w} \mathrm{w}^{-1}\right)\right.$ of the CDW) (KIM et al., 1994). However, Rps. palustris has a number of advantages: (1) The $\mathrm{CH} 12$ strain was isolated from chicken feces, so it might grow in wastewater, especially wastewater containing organic matter. In addition, (2) CH12 strain could secrete proteinase outside the cell (data not shown). Thus, wastewater used as growth medium might be applied. Rps. palustris is capable of producing $\mathrm{H}_{2}$ (CARLOZZI; SACCHI, 2001). (3) $\mathrm{H}_{2}$ is proposed to be environmentally friendly fuel to the world in the future. Thus, all benefits mentioned above make $\mathrm{CH} 12$ strain an attractive model for the study of the wastewater treatment, $\mathrm{H}_{2}$ production, PHB production, and/ or composition of general component of the cells.

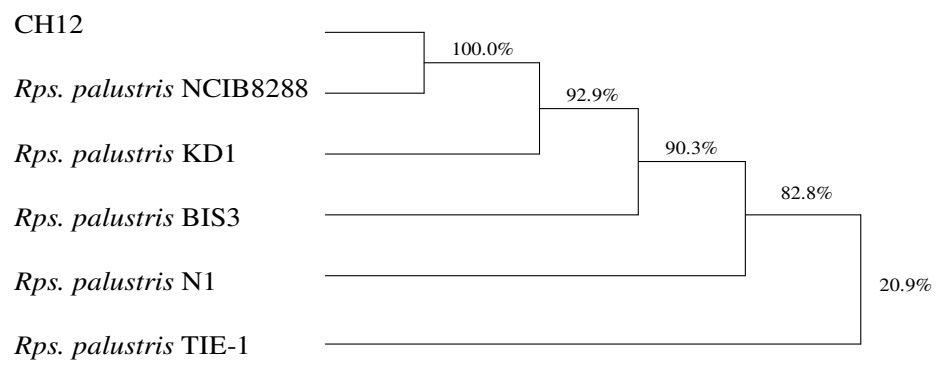

Figure 2. The evolutionary tree between $\mathrm{CH} 12$ and other Rhodopseudomonas palustris strains The percentage shown in parentheses indicated the similarity of $16 \mathrm{~S}$ rDNA sequence of $\mathrm{CH} 12$ to those of others. 
A purple non-sulfur bacterium...

To increase the expression of PHB synthesizing genes of $\mathrm{CH} 12$ strain, genetic manipulation need to be carried out for further study. Firstly the synthase was assayed and determined with standard curve of coenzyme A
TANSKUL, S; SRISAI, S.; NUALLA-ONG, A.

(CoA). The activity of PHA synthase of crude enzyme was $0.111\left(\mathrm{~A}_{412}\right)$ or 25.0 unit $/ \mathrm{mL}$. A standard curve of $\mathrm{CoA}$ versus $\mathrm{A}_{412}$ was shown in Figure 3.

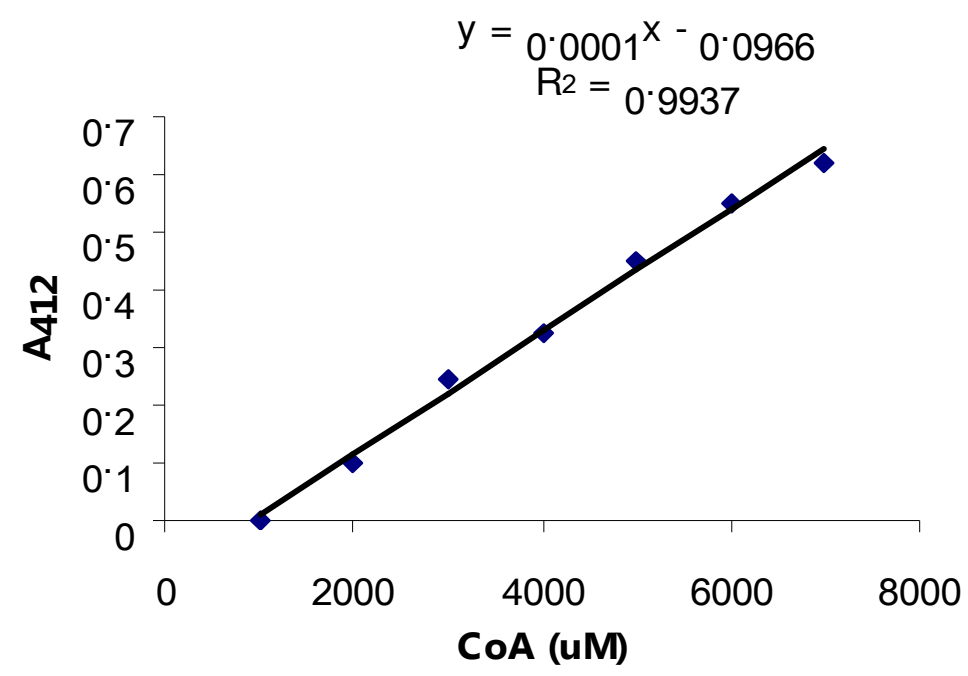

Figure 3. Standard curve of coenzyme A (CoA)

According to the multiple sequence alignment using Clustal $\mathrm{X}$ program, there were 5 groups giving a well-conserved sequence (Fig. 4). They were as follows: hydroxyalkanoic acid synthase, class I (Rhodopseudomonas palustris BisA53), Poly(R)-hydroxyalkanoic acid synthase, class I (Rhodopseudomonas palustris BisB18), hydroxyalkanoic acid synthase, class I (Rhodopseudomonas palustris TIE-1), phbC Poly(R)-hydroxyalkanoic acid synthase, class I (Rhodopseudomonas palustris CGA009), and Poly(R)-hydroxyalkanoic acid synthase, class I (Rhodopseudomonas palustris $\mathrm{HaA} 2$ ).

\section{A53}

GAGCTGATGCAGCTCATCCAGTATCACCCGACCACCGAAACCGTGCTGCGCACGCCACTG 771 BisB18

GAATTGATGCAGCTGATCCAATATCAGCCGACCACCGAGAACGTGCTGCGCACGCCGCTG 774 TIE-1

GAAATCATGCAGCTCATCCAGTATGAGCCCGCCACCGCGACGGTGCAGCGCACGCCGCTG 774 CGA009

GAGATCATGCAGCTCATCCAGTATGAGCCCGCCACCGCGACGGTGCAGCGCACGCCGCTG 774 HaA2

GAGATCATGCAACTGATCCAGTACACGCCCGCGACCGAGACGGTGCTGCGCACGCCTCTG 774 ******************* $* * * * * * * * * * * * * * * * * * * * * * * * * *$

A53

CTGATCGTGCCGCCGTGGATCAACAAATACTACATCCTCGATTTGAAGCCGGAAAAATCC 831 BisB18

TTGATCGTGCCGCCGTGGATCAACAAGTATTACATTCTCGACCTCAAGCCGGAAAAATCC 834 TIE-1

CTGATCGTGCCGCCGTGGATCAACAAGTACTACATTCTCGATCTGAAGCCCGAGAAGTCG 834 CGA009

CTGATCGTGCCGCCGTGGATCAACAAGTACTACATTCTCGACCTGAAGCCCGAGAAGTCG 834 $\mathrm{HaA} 2$

CTGATCGTGCCGCCATGGATCAACAAGTTCTACATTCTCGATCTCAAGCCCGAGAAGTCG 834 


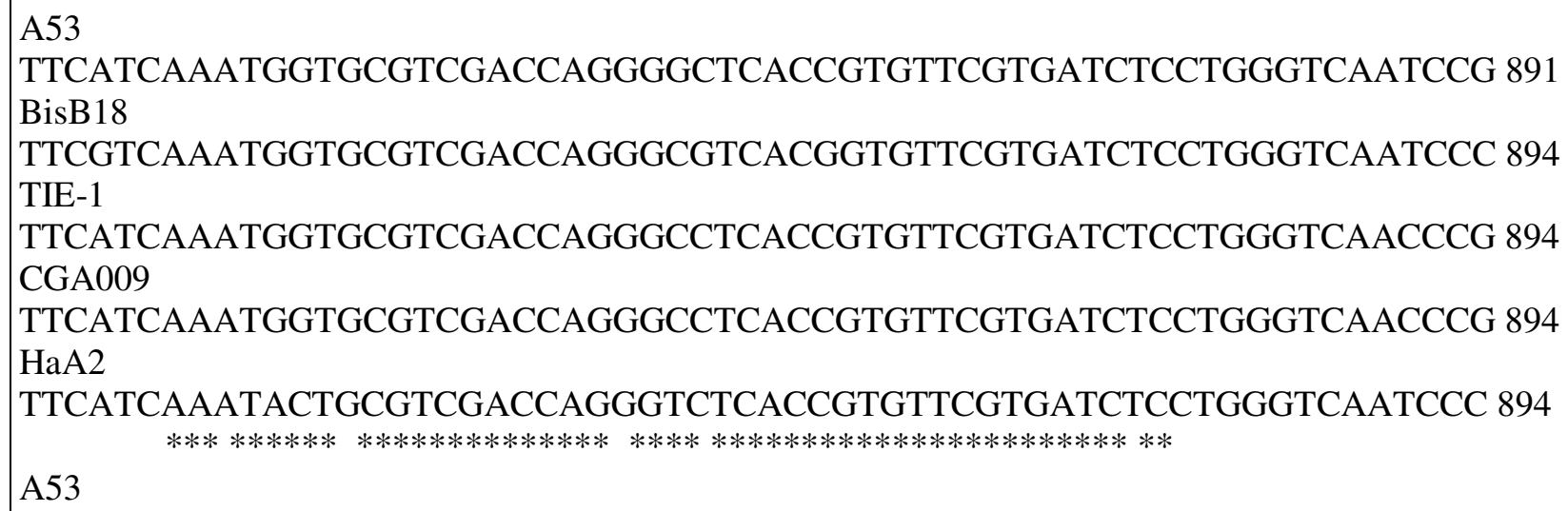


A53

TTCGTCGACGAGGAGCAGATCGCGGCGCTGGAGCAGGAGATGAAGTCTGTCGGCGTGCTC 1191 BisB18

TTCGTCGACGAGGATCAGATCGCCGCGTTGGAGCGCGAGATGCAGGCCAGCGGCGTGCTG 1194 TIE-1

TTCGTCGACGAGGAGCAGATTTCCGCGGTCGAACGCGAGATGAAGGTCACCGGCGTGCTC 1194 CGA009

TTCGTCGACGAGGAGCAGATTTCCGCGGTCGAACGCGAGATGAAGGTCACCGGCGTGCTC 1194

$\mathrm{HaA} 2$

TTCGTCGACGAGGGCCAGATCTCGGCGCTGGAGCGCGACATGCAGACGACCGGCGTGCTC 1194 $* * * * * * * * * * * * * * * * * * * * * * * * * * * * * * * * * * \quad * * * * * * * * *$

A53

GAGGGCTCCAAGATGGCGATGGCCTTCAACATGCTGCGCTCGAACGACCTGATCTGGTCC 1251 BisB18

GAAGGCTCGAAGATGGCGATGGCCTTCAACATGCTGCGCTCCAACGACCTGATCTGGTCC 1254

TIE-1

GAAGGCGCCAAGATGGCGATGGCCTTCAACATGCTGCGGCCGAACGATCTGATCTGGTCC 1254

CGA009

GAAGGCGCCAAGATGGCGATGGCCTTCAACATGCTGCGGCCGAACGATCTGATCTGGTCC 1254

$\mathrm{HaA} 2$

GAAGGCGCCAGGATGGCGATGGCGTTCAACATGCTGCGGTCGAACGACCTGATCTGGTCC 1254

A53

$* * * * * * * * * * * * * * * * * * * * * * * * * * * * * * * * * * * * * * * * * * * * * * * * * * * *$

TACGTCGTCAATAACTACCTGAAGGGCAAGTCGCCCTCGCCCTTCGACCTGCTGCACTGG 1311 BisB18

TATGTGGTCAATAACTATCTGAAGGGCCAGCCGCCGTCGGCGTTCGACCTGTTGCACTGG 1314 TIE-1

TACGTCGTCAATAACTACCTGAAGGGCCAGCCGCCGCAGGCGTTCGACCTGCTGCACTGG 1314 CGA009

TACGTCGTCAACAACTACCTGAAGGGACAGCCGCCGCAGGCGTTCGACCTGCTGCACTGG 1314 $\mathrm{HaA} 2$

TATGTGGTCAGCAACTATCTGAAGGGCCAGCCGCCCGCCGCGTTCGACCTGCTGCACTGG 1314 ********* ********************* $* * * * * * * * * * * * * * * * * * *$

Figure 4. Multiple sequence alignment of phaC gene of Rhodopseudomonas palustris strains: Rhodopseudomonas palustris BisA53 (A53), Rhodopseudomonas palustris BisB18 (BisB18), Rhodopseudomonas palustris TIE-1 (TIE-1), Rhodopseudomonas palustris CGA009 (CGA009), and Rhodopseudomonas palustris $\mathrm{HaA} 2$ (HaA2). The star represents the highly conserved region shown in panel.

The conserved regions in sequence alignments were used for designing primer. The forward and reverse primers were GGCAAGGTGATCTTCCAGAACG and CGCAGCATGTTGAASGCCATCG, respectively. Amplification of the conserved region between positions 766 and 1304 resulted in 538 bp products
(Table 2). After purification of the PCR product and performed on $1.0 \%$ agarose gel electrophoresis, the 538 bp of purified PCR product was obtained. Thus, the designed primers had a good match the DNA template of $\mathrm{CH} 12$ strain. This result correlate to the report on phaC synthases play an important role in PHB production (AMARA; MOAWAD, 2011).

Table 2 Primer design of $p h a \mathrm{C}$ gene

\begin{tabular}{cccccc}
\hline $\begin{array}{c}\text { Primer } \\
\text { Name }\end{array}$ & Primer Sequence & $\begin{array}{c}\text { Tm } \\
\left({ }^{\circ} \mathbf{C}\right)\end{array}$ & $\begin{array}{c}\text { Length } \\
\text { (bases) }\end{array}$ & $\begin{array}{c}\text { Product } \\
\text { Region }\end{array}$ & $\begin{array}{c}\text { Product } \\
\text { Length } \\
\text { (bases) }\end{array}$ \\
\hline $\begin{array}{c}\text { Forward } \\
\text { Reverse }\end{array}$ & GGCAAGGTGATCTTCCAGAACG & 51.6 & 22 & $766-1304$ & 538 \\
\hline
\end{tabular}




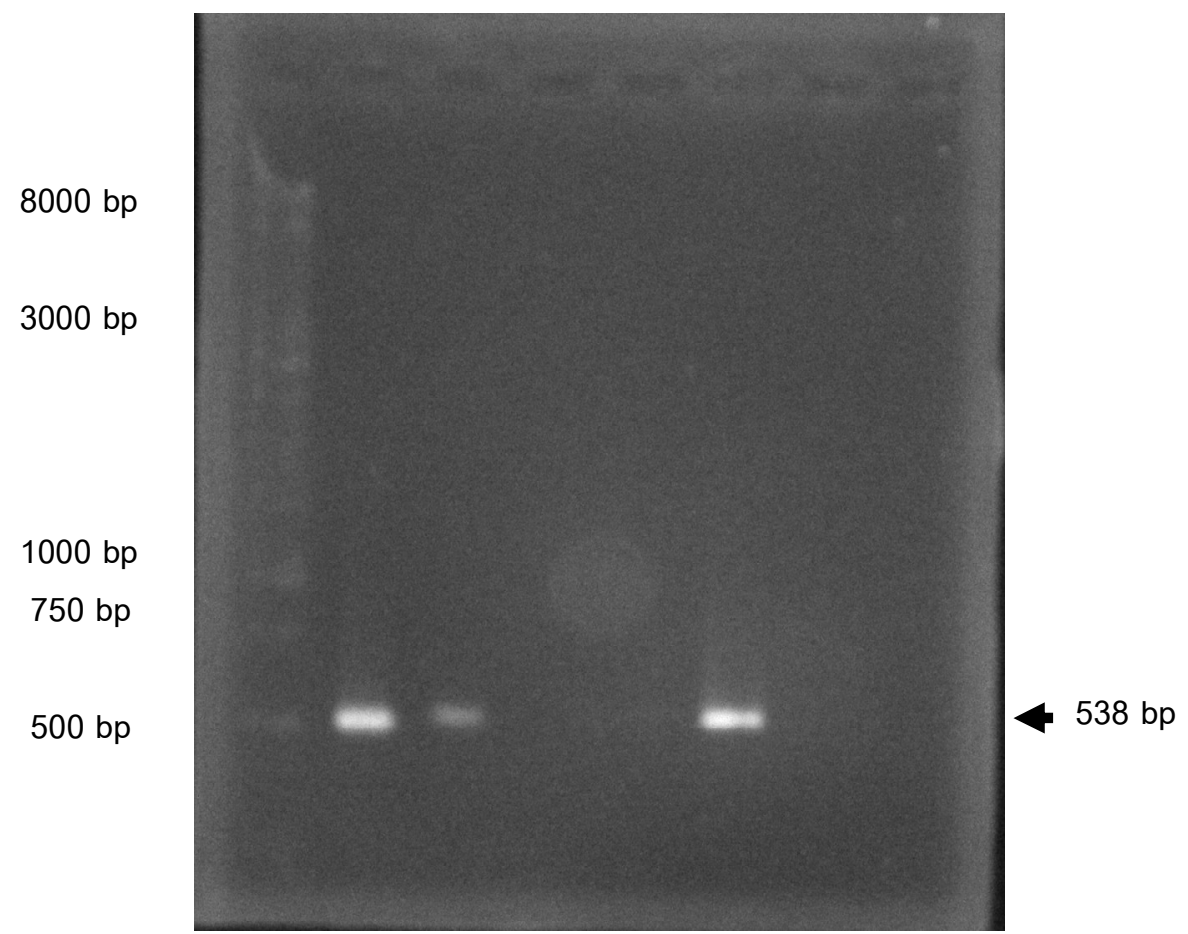

Figure 5. Amplified phaC gene after purification by PureLinkTM Quick Gel Extraction Kit (Invitrogen)

\section{CONCLUSIONS}

A purple non-sulfur bacterium capable of accumulating PHB inside the cells could be screened from chicken feces. It was named $\mathrm{CH} 12$ and identified as Rhodopseudomonas palustris based on taxonomic characteristics and 16S rDNA sequence analysis.

The CH12 strain had PHA synthase activity of 25.0 units $/ \mathrm{mL}$. The conserved region of $p h a \mathrm{C}$ gene of $\mathrm{CH} 12$ strain could be aligned and selected among 5 related strains.

\section{ACKNOWLEDGEMENT}

This work was supported by the budget revenue of Faculty of Science, Prince of Songkla University, and the government budget of Prince of Songkla University.

RESUMO: Este estudo teve como objetivo rastrear bactérias púrpuras não sulfurosas capazes de acumular grânulos ou polihidroxibutirato (PHB) dentro das células, identificar a estirpe potente, ensaiar a enzima ou PHA sintaxe, e comparar com o gene PHB sintase com aquele de estirpes relacionadas. Um total de 58 estirpes de bactérias púrpuras não sulfurosas foram isoladas a partir de 108 amostras de fezes de galinhas na granja produtora de ovos do Departamento de Ciência Animal, Faculdade de Recursos Naturais da Universidade Prince of Songkla, Hat Yai, Tailândia. Depois de cultivar as bactérias em um substrato de glutamato/malato (GM), sem ácido glutâmico adicionado, sob luz (3000 lux) a 35 ${ }^{\circ} \mathrm{C}$ durante 5 dias, os grânulos de biopolímeros intracelulares das bactérias foram observados utilizando um microscópio confocal (do inglês Confocal Laser Scanning Microscope - CLSM) com comprimentos de onda de excitação e emissão de 530 e $605 \mathrm{~nm}$, respectivamente. A cromatografia gasosa (do inglês Gas chromatography - GC) foi realizada para uma análise quantitativa de PHB. Havia 5 estirpes, CH12, CH52, CH72, CH90 e CH92, que mostraram grânulos biopoliméricos quando submetidos ao CLSM, e PHB-5 acumulado de 1.7, 1.5, 1.4 and 1.8\% (w w-1) do peso celular seco (do inglês cell dry weight - CDW), respectivamente. A análise da sequência do rDNA 16S da estirpe CH12 demonstrou uma alta correlação de homologia de $100 \%$ para aquela da estirpe NCIB8288 da Rhodopseudomonas palustris. Em relação às características taxonômicas e da análise da sequência do rDNA 16S, a estirpe CH12 foi identificada como Rps. palustris NCIB8288. A atividade da PHA sintase do extrato bruto da estirpe $\mathrm{CH} 12$ foi de 25 unidades/mL. As regiões conservadas puderam ser alinhadas e selecionadas entre 5 estirpes de Rhodopseudomonas palustris (BisA53, TIE-1, CGA009, HaA2 e BisB18). O produto purificado da reação em cadeia da polimerase - PCR foi obtido para estudos futuros.

PALAVRAS-CHAVE: Fezes de galinha. Rhodopseudomonas palustris. Bioplástico. Polihidroxibutirato. Gene phaC. Região conservada. 


\section{REFERENCES}

ALDERETE, J. E.; KARL, D. W.; PARK, C. H. Production of poly(hydroxybutyrate) homopolymer and copolymer from ethanol and propanol in a fed-batch culture. Biotechnology Progress, v. 9, p. 520-525, 1993. http://dx.doi.org/10.1021/bp00023a011

AMARA, A. A.; MOAWAD, H. PHAC synthases and PHA depolymerases: The enzymes that produce and degrade plastic. IIUM. Engineering Journal, V. 12, n. 4, p. 21-37, 2011.

BOURQUE, D.; POMERLEAU, Y.; GROLEAU, D. High-cell-density production of poly- $\beta$-hydroxybutyrate (PHB) from methanol by Methylobacterium extorquens: production of high-molecular-mass PHB. Applied Microbiology and Biotechnology, v. 44, p. 367-376, 1995. http://dx.doi.org/10.1007/BF00169931

BRANDL, H.; KNEE, E. J., Jr.; FULLER, R. C.; GROSS, R.A.; LENZ, R. W. Ability of the phototrophic bacterium Rhodospirillum rubrum to produce various poly(beta-hydroxyalkanoates): potential sources for biodegradable polyesters. International Journal of Biological Macromolecules, v. 11, p. 49-55, 1989. http://dx.doi.org/10.1016/0141-8130(89)90040-8

BRANDL, H.; GROSS, R. A.; LENZ, R. W.; LLOYD, R.; FULLER, R. C. The accumulation of poly(3hydroxyalkanoates) in Rhodobacter sphaeroides. Archives of Microbiology. v. 155, p. 337-340, 1991. http://dx.doi.org/10.1007/BF00243452

BYROM, D. Polyhydroxyalkanoates. In: MOBLEY, D. P. Plastics from microbes: microbial synthesis of polymers and polymer precursors. Hanser Munich, 1994. p. 5-33.

CARLOZZI, P.; SACCHI, A. Biomass production and studies on Rhodopseudomonas palustris grown in an outdoor, temperature controlled, underwater tubular photobioreactor. Journal of Biotechnology, p. 239-249, 2001. http://dx.doi.org/10.1016/S0168-1656(01)00280-2

DAI, D.; REUSCH, R. N. Poly-3-hydroxybutyrate synthase from the periplasm of Escherichia coli. Biochemical and Biophysical Research Communications, v. 374, p. 485-489, 2008. http://dx.doi.org/10.1016/j.bbrc.2008.07.043

De PHILIPPIS, R.; ENA, A.; GUASTIINI, M.; SILI, C.; VINCENZINI, M. Factors affecting poly- $\beta$ hydroxybutyrate accumulation in cyanobacteria and in purple non-sulfur bacteria. FEMS Microbiology Letters, v. 103, p. 187-194, 1992. http://dx.doi.org/10.1016/0378-1097(92)90309-C http://dx.doi.org/10.1111/j.1574-6968.1992.tb05837.x

DUNLOP, W. F.; ROBARDS, A. W. Ultrastructural study of poly- $\beta$-hydroxybutyrate granules from Bacillus cereus. Journal of Bacteriology, v. 114, p. 1271-1280, 1973.

ESTEVE, I.; MAS, J.;GAJU, N.; GUERRERO, R. Cellular content of storage inclusions in purple sulfur bacteria determined by ultrathin sections. Microbiologia, v. 12, p. 563-570, 1996.

GOBI, K.; VADIVELU, V. M. Aerobic dynamic feeding as a strategy for in situ accumulation of polyhydroxyalkanoate in aerobic granules. Bioresource Technology, v. 161, p. 441-445, 2014. http://dx.doi.org/10.1016/j.biortech.2014.03.104

GUEZENNEC, J.; ROCCHICCIOLI, F.; MACCARON-GOMEZ, B.; KHELIFA, N.; DUSSAUZE, J.; RIMBAULT, A. Occurrence of 3-hydroxyalkanoic acids in sediments from the Guaymas basin (Gulf of California). FEMS Microbiology Ecology, v. 26, p. 335-344, 1998. http://dx.doi.org/10.1111/j.15746941.1998.tb00518.x

HOLT, J. G.; OSTLE, A. G. Nile blue A as a fluorescent stain for poly- $\beta$-hydroxybutyrate. Applied and Environmental Microbiology, v. 44, n. 1, p. 238-241, 1982. 
IMHOFF, J. F.; TRUPER, H. G. In: STALEY, J. T.; BRYANT, M. P.; PFENNIG, N.; HOLT, J. G. Anoxygenic phototrophic bacteria. Bergey's Manual of Systematic Bacteriology, v. 3, 1989. p. 1678-1682.

JACKSON, D. E.; SRIENC, F. Novel methods to synthesize polyhydroxyalkanoates. Biochemical Engineering VIII. Annals of the New York Academy of Sciences, v. 745, p. 134-148, 1994.

http://dx.doi.org/10.1111/j.1749-6632.1994.tb44369.x

KHATIPOV, E.; MIYAKE, M.; MIYAKE, J.; ASADA, Y. Accumulation of poly- $\beta$-hydroxybutyrate by Rhodobacter sphaeroides on various carbon and nitrogen substrates. FEMS Microbiology Letters, v. 162, p. 39-45, 1998.http://dx.doi.org/10.1111/j.1574-6968.1998.tb12976.x

http://dx.doi.org/10.1016/S0378-1097(98)00099-8

KIM, B. S.; LEE, S. C.; LEE, S. Y.; CHANG, H. N.; CHANG, Y. K.; WOO, S. I. Production of poly(3hydroxybutyric acid) by fed-batch culture of Alcaligenes eutrophus with glucose concentration control. Biotechnology and Bioengineering, v. 43, p. 892-898, 1994. http://dx.doi.org/10.1002/bit.260430908

KOBAYASHI, K.; KURATA, S. The mass culture and cell utilization of photosynthetic bacteria. Process Biochemistry, v. 13, p. 27-30, 1978.

KOBAYASHI, M.; KOBAYASHI, M. In: BLANKENSHIP, R. E.; MADIGAN, M. T.; BAUER, C. E. Waste Remediation and treatment using anoxygenic phototrophic bacteria. Anoxygenic Photosynthetic Bacteria, 1995. p. 1269-1282.

LOPEZ, N. I.; FLOCCARI, M. E.; STEINBüCHEL, A.; GARCIA, A. F.; MENDEZ, B. S. Effect of poly(3hydroxybutyrate)(PHB) content on the starvation-survival of bacteria in natural waters. FEMS Microbiology Ecology, v. 16, p. 95-102, 1995. http://dx.doi.org/10.1016/0168-6496(94)00073-6

http://dx.doi.org/10.1111/j.1574-6941.1995.tb00273.x

MINO, T.; van LOOSDRECHT, M. C. M.; HEIJNEN, J. J. Review: Microbiology and Biochemistry of Enhanced Biological Phosphate Removal Process. Water Research, v. 32, p. 3193-3207, 1998. http://dx.doi.org/10.1016/S0043-1354(98)00129-8

MUKHOPADHYAY, M.; PATRA, A.; PAUL, A. K. Production of poly(3-hydroxybutyrate) and poly(3hydroxybutyrate-co-3-hydroxyvalerate) by Rhodopseudomonas palustris SP5212. World Journal of Microbiology and Biotechnology, v. 21, p. 765-769, 2005. http://dx.doi.org/10.1007/s11274-004-5565-y

NDOYE, I.; DEBILLY, S. F.; VASSE, J.; DREYFUS, B.; TRUCHET, G. Root nodulation of Sesbania rostrata. Journal of Bacteriology, v. 176, p. 1060-1068, 1994.

PFENNIG, N.; TRUPER, H. G. Anoxygenic phototrophic bacteria. In: STALEY, J. T.; BRYANT, M. P.; PFENNIG, N.; HOLT, J. G. (Ed.) Bergey's Manual of Systematic Bacteriology. v. 3, Baltimore: Williams and Wilkins, 1989. p. 1635-1637.

RIIS, V.; MAI, W. Gas chromatographic determination of poly- $\beta$-hydroxybutyric acid in microbial biomass after hydrochloric acid propanolysis. Journal of Chromatography A., v. 445, p. 285-289, 1988.

http://dx.doi.org/10.1016/S0021-9673(01)84535-0

SALEHIZADEH, H.; LOOSDRECHT VAN, M. C. M. Production of polyhydroxyalkanoates by mixed culture: recent trends and biotechnological importance. Biotechnology Advances, v. 22, no. 3, p. 261-279, 2004. http://dx.doi.org/10.1016/j.biotechadv.2003.09.003

SAMBROOK, J.; FRITSCH, E. F.; MANIATIS, T. Molecular cloning: A laboratory manual. $2^{\text {nd }}$ ed. New York: Cold Spring Harbor Laboratory, 1989. 
SAWAYAMA, S.; HANADA, S.; KAMAGATA, Y. Isolation and characterization of phototrophic bacteria growing in lighted upflow anaerobic sludge blanket reactor. Journal of Bioscience and Bioengineering, v. 89, no. 4, p. 396-399, 2000. http://dx.doi.org/10.1016/S1389-1723(00)88967-7

SAWAYAMA, S.; TSUKAHARA, K.; YAGISHITA, T.; HANADA, S. Characterization of lighted upflow anaerobic sludge blanket (LUASB) method under sulfate-rich conditions. Journal of Bioscience and Bioengineering, v. 91, no. 2, p. 195-201, 2001. http://dx.doi.org/10.1016/S1389-1723(01)80065-7

STEINBüCHEL, A.; VALENTIN, H. E. Diversity of bacterial polyhydroxyalkanoic acids. FEMS Microbiology Letters, V. 128, p. 219-228, 1995. http://dx.doi.org/10.1016/0378-1097(95)00125-O http://dx.doi.org/10.1111/j.1574-6968.1995.tb07528.x

SUZUKI, T.; YAMANE, T.; SHIMIZU, S. Mass production of poly- $\beta$-hydroxybutyric acid by fully automatic fed-batch culture of methylotroph. Applied Microbiology and Biotechnology, v. 23, p. 322-329, 1986. http://dx.doi.org/10.1007/BF00257027 